\title{
Efek Mediasi Work Engangement terhadap Kinerja Individu Berbasis Leader Member Exchange dan Iklim Organisasi
}

\author{
Erlangga Dipo Prayugo a ${ }^{a}$ Gunarianto ${ }^{b}$, Adya Hermawati ${ }^{c}$ \\ aUniversitasWidyagama Malang, gun_uwg@yahoo.co.id \\ bUniversitasWidyagama Malang, dipoprayugo@gmail.com \\ 'UniversitasWidyagama Malang, wati_wati38@yahoo.co.id
}

\begin{abstract}
A b s t r a k
Tujuan penelitian adalah untuk mendapatkan bukti empiris mengenai pengaruh Leader Member Exchange dan iklim organisasi terhadap kinerja, serta peran work engagement sebagai variabel mediasi dengan melakukan studi pada Personil Depo Pemeliharaan 30 Lanud Abdulrachman Saleh Malang, mencakup Tamtama, Bintara, dan Perwira yang berjumlah 250 personel. Teknik penarikan sampel yang digunakan yaitu Proportional Random Sampling. Ukuran sampel ditentukan dengan rumus slovin yang dibulatkan menjadi 100 responden. Berdasarkan data mentah atau data primer yang terkumpul dari responden, selanjutnya diproses melalui software:1) SPSS for windows yang menghasilkan informasi atau data untuk keperluan analisis karakteristik responden dan statistik deskriptif, dan 2) Smart Partial Least Square (PLS) yang menghasilkan data untuk keperluan pengujian instrumen penelitian (outer model) dan analisis statistik inferensial berupa analisis jalur (inner model), dan pengujian hipotesis. Hasil penelitian menunjukkan bahwa Leader Member Exchange yang semakin baik mampu meningkatkan work engagement. Iklim organisasi yang semakin baik mampu meningkatkan work engagement. Leader member exchange yang semakin baik tidak mampu meningkatkan kinerja. Iklim organisasi yang semakin baik mampu meningkatkan Kinerja. Work engagement yang semakin baik mampu meningkatkan kinerja. Leader member exchange yang semakin baik mampu meningkatkan kinerja yang dimediasi work engagement. Iklim Organisasi yang semakin baik mampu meningkatkan Kinerja yang dimediasi work engagement.
\end{abstract}

Kata Kunci: Leader Member Exchange, Iklim Organisasi, Work Engagement, Kinerja.

\section{A b s t r a c t}

The purpose of the study was to obtain empirical evidence regarding the influence of LeaderMember Exchange and organizational climate on performance, as well as the role of work engagement as a mediating variable by conducting a study on the Personnel of the Maintenance Depo 30 Abdulrachman Saleh Malang Air Force Base, including enlisted personnel, noncommissioned officers, and officers totaling 250 personnel. The sample size was determined by the slovin formula, which was rounded up to 100 respondents. Based on raw data or primary data collected from respondents, then processed through software: 1) SPSS for windows which produces information or data to analyze respondent characteristics and descriptive statistics, and 2) Smart Partial Least Square (PLS), which produces data to test research instruments (outer model) and inferential statistical analysis in the form of path analysis (inner model), and hypothesis testing. The results showed that a better Leader-Member Exchange could increase work engagement. A better organizational climate can increase work engagement. LeaderMember Exchange that is getting better is not able to improve performance. A better corporate environment can improve performance. Better work engagement can improve performance. Better leader-member exchange can improve performance mediated by work engagement. Better organizational climate can improve performance mediated by work engagement.

Keywords: Leader Member Exchange, organizational climate, work engagement, performance. 


\section{Pendahuluan}

Kinerja organisasi, baik pada organisasi swasta, pemerintah, maupun militer sangat ditentukan oleh kinerja sumber daya manusia yang terdapat didalamnya, baik secara individu maupun berkelompok. Harris et al., (2014) mengemukakan bahwa kinerja organisasi tidak dapat dinilai dari per-individu dalam organisasi, namun keseluruhan pegawai yang ada di sebuah organisasi. Hal tersebut juga tergambarkan pada organisasi militer Depo Pemeliharaan (Depohar) 30 Lanud Abdulrachman Saleh Malang.

Sebagaimana anggota pada satuan lainnya, anggota Depohar 30 dalam pelaksanaan tugasnya dituntut untuk memiliki etos kerja yang tinggi dengan cara memelihara dan terus meningkatkan prestasi kerja satuan yang telah dicapai. Dalam konteks ini, prestasi kerja mempunyai makna dua hal, yaitu: pertama, secara kuantitas mengacu pada "hasil", dari suatu kerja yang dilakukan seperti jumlah luaran anggota, baik secara individual atau kelompok persatuan waktu. Kedua, dari sudut kualitas, juga prestasi kerja mengacu pada "bagaimana sempurna" anggota itu melakukan pekerjaan. Indikator penilaian atau pengukuran kinerja yang dipergunakan pada Depohar 30 adalah 1) Pelaksanaan kegiatan/program, mengacu pada pendekatan "Efisiensi", 2) Pelaksanaan kegiatan personel, mengacu pada pendekatan "Efektivitas", dan 3) Kualitas penugasan, mengacu pada pendekatan "Kualitas".

Berdasarkan hasil evaluasi Komandan Depohar 30, kinerja satuan (organisasi) yang dicapai masih perlu ditingkatkan untuk masa-masa yang datang pada tingkat optimal sebagaimana tujuan yang ditetapkan, berprinsip konsep kinerja (performance) sebagai sebuah pencapaian hasil atau degree of accomplishtment. Hal ini berarti bahwa, kinerja suatu organisasi itu dapat dilihat dari tingkatan sejauh mana organisasi dapat mencapai tujuan yang didasarkan pada tujuan yang sudah ditetapkan sebelumnya. Belum optimalnya capaian prestasi kerja Depohar 30 tersebut, salah satunya tak terlepas dari upaya dan hasil kerja personil dalam pelaksanaan tugasnya, baik secara individu dan berkelompok. Sebagaimana data Tahun 2020 dapat diketahui bahwa capaian kinerja ratarata personil masih perlu ditingkatkan karena belum mencapai parameter capaian kinerja, yakni sebesar 94,5 atau masih dibawah angka 100, dimana capaian rata-rata indikator untuk: 1) Pelaksanaan Kegiatan/Program dengan nilai 94,5; 2) Pelaksanaan Kegiatan Personel dengan nilai 93,5 dan; 3) Kualitas Penugasan dengan nilai 95,5.

Berdasarkan hasil pengamatan dan evaluasi yang Peneliti lakukan pada tempat penelitian, belum optimalnya capaian prestasi kerja Depohar 30 yang terkait dengan faktor lingkungan adalah: 1) Kepemimpinan, tingkat kedekatan dari hubungan dan interaksi antara atasan dan bawahan, dan; 2) Iklim organisasi, Faktori ndividu, yakni Keterikatan/keterlibatankerja (work engagement).

Menurut Luthans et al., (2011) mengemukakan bahwa salah satu faktor yang mempengaruhi pretasi kerja karyawan adalah pemimpin. Salah satu yang harus diperhatikan oleh para pemimpin adalah kualitas hubungan antara pemimpin dan pegawai yang dapat dinilai dari tingkat kedekatan dari hubungan dan interaksi antara pemimpinan (atasan) dan bawahan. Hasil temuan Findiklı et al., (2015) menunjukkan bahwa hubungan atasan-bawahan Leader Member Exchange (LMX) berpengaruh terhadap peningkatan 
kinerja SDM. Dengan kata lain, kuatnya hubungan atasan-bawahan atau persepsi yang muncul dikalangan pekerja mengenai positifnya hubungan atasan-bawahan akan berpengaruh terhadap peningkatan kinerja SDM. Berbeda dengan hasil penelitian tersebut, Hutama \& Goenawan (2017) menemukan bahwa Leader Member Exchange secara parsial berkorelasi secara positif tetapi tidak signifikan terhadap kinerja karyawan.

Disamping Leader Member Exchange (LMX), fenomena lainnya yang terkait dengan permasalahan belum optimalnya capaian kinerja personel Depohar 30 yang berhubungan faktor lingkungan kerja adalah iklim organisasi. Menurut Liliweri (2014) iklim organisasi (organizational climate) dapat diartikan sebagai pola-pola perilaku, sikap dan perasaan yang ditampilkan berulang-ulang yang dijadikan sebagai karakteristik kehidupan organisasai. Oleh karena itu, iklim organisasi menjadi sebuah unsur yang penting dalam organisasi karena dapat memberikan nilai-nilai, sikap, serta meningkatkan kinerja pegawai dalam pencapaian organisasinya, karena nilai-nilai dari setiap individu yang berlainan harus diketahui oleh organisasi agar dapat digunakan untuk menilai pegawai yang potensial dan menetapkan nilai-nilai mereka segaris dengan nilai dominan organisasi. Iklim organisasi memainkan peran langsung dalam meningkatkan perilaku dan kinerja individu. Penelitian lainnya juga menunjukkan hasil yang sama, seperti Arakal \& Mampilly (2013); Putra et al., (2020); Shafarila \& Supardi (2016) menyimpulkan bahwa iklim organisasi berpengaruh yang positif dan signifikan terhadap kinerja pegawai.

Faktor individu yang terkait dengan permasalahan belum optimalnya capaian kinerja personel Depohar 30 adalah keterlibatan kerja, atau dalam telah Perilaku Organisasi populer diisitilahkan dengan "Work Engagement". Hasil penelitian Astuti et al., (2016); Justina et al., (2019); Sepdiningtyas (2016) membuktikan bahwa Work engagement berdampak positif terhadap kinerja pegawai. Berbeda dengan hasil penelitian tersebut, menurut Rahmadalena \& Asmanita (2020) menemukan bahwa employee engagement tidak berpengaruh signifikan terhadap kinerja karyawan.

Penelitian tentang Leader Member Exchange (LMX) dan iklim organisasi sebagai prediktor (variabel yang mempengaruhi) work engagement cukup banyak dilakukan peneliti sebelumnya. Menurut Dewi et al., (2019) bahwa LMX mempengaruhi secara langsung dan positif signifikan terhadap work engagement. Demikian pula LMX berhubungan positif serta memprediksi work engagement secara signifikan. Dalam konteks penelitian yang serupa, hasil penelitian lainnya menunjukkan adanya inkonsistensi atas hubungan LMX dengan work engagement. Penelitian Meng \& Wu (2015), Sari (2016), serta Wulandari \& Ratnaningsih (2017) menemukan bahwa tidak terdapat hubungan yang signifikan antara LMX dengan work engagement. Mereka menegaskan bahwa semakin tinggi kualitas hubungan antara atasan dan bawahan (LMX) tetapi hasilnya tidak konsisten atau signifikan terhadap work engagement.

Enam komponen kehidupan kerja yang berpotensi sebagai jalan untuk mengkonsepkan climate for engagement. Ketika diukur sebagai konstruk iklim (pada tingkat unit atau organisasi), enam komponen kehidupan kerja (beban kerja, kontrol, reward, komunitas, keadilan, dan nilai-nilai) dapat mempengaruhi persepsi karyawan 
terhadap tuntutan pekerjaan dan sumber daya kerja yang pada gilirannya mempengaruhi work engagement. Hasil penelitian membuktikan hubungan tersebut. Menurut Putra et al., (2020) menyimpulkan dalam penelitiannya bahwa persepsi iklim organisasi berpengaruh positif dan signifikan terhadap employee engagement. Berbeda dengan hasil penelitian tersebut, menurut Apriani et al., (2019) menemukan bahwa iklim organisasi tidak dapat memprediksi keterlibatan kerja (work engagement).

Penelitian tentang anteseden atau prediktor work engagement serta hasilnya, cukup banyak menarik perhatian dari praktisi bisnis, peneliti akademis, dan pemerintah untuk memahami peran work engagement sebagai variabel mediasi (mediator) atas pengaruh variabel bebas (eksogen) terhadap variabel terikat (endogen). Menurut Salu \& Hartijasi (2018); Putra et al., (2020) menemukan bahwa work engagement memiliki efek positif sebagai mediator untuk hubungan antara job resources dan kepemimpinan transformational terhadap komitmen organisasi dan job performance. Justina et al., (2019) menyimpulkan bahwa work engagement memediasi hubungan antara LeaderMember Exchange dan kinerja karyawan. Menurut Putra et al., (2020) dari hasil penelitiannya menyimpulkan bahwa employee engagement memediasi pengaruh positif dan signifikan iklim organisasional terhadap kinerja karyawan.

Berdasarkan uraian diatas, dapat diketahui bahwa pada Depo Pemeliharaan 30 Lanud Abdulrachman Saleh di Malang sedang menghadapi permasalahan terkait belum optimalnya capaian kinerja personel yang disebabkan leader member exchange (LMX), iklim organisasi, dan work engagement. Teori dan studi empiris menyebutkan bahwa kinerja memiliki hubungan dengan leader member exchange (LMX), iklim organisasi, dan work engagement, walaupun hasil penelitian terdahulu juga menemukan adanya inkonsistensi pengaruh langsung atas hubungan tersebut. Pada penelitian lainnya, beberapa peneliti mencoba mengeksplorasi hubungan antara LMX dan iklim organisasi terhadap kinerja dengan menempatkan work engagement sebagai variabel mediasi. Hasil penelitian menunjukkan bahwa work engagement memediasi hubungan antara Leader Member Exchange (LMX) dan iklim bisnis dengan kinerja. Berdasarkan atas uraian latar belakang, maka penelitian ini bertujuan untuk mengetahui pengaruh Leader Member Exchange dan iklim organisasi terhadap kinerja, serta peran work engagement sebagai variabel mediasi.

\section{Landasan Teori}

Menurut Harris et al., (2014) menyatakan bahwa keberhasilan atau kegagalan yang dialami sebagian besar organisasi ditentukan oleh kualitas kepemimpinan yang dimiliki orang-orang yang diserahi tugas memimpin organisasi. Kemampuan seorang pemimpin dalam mempengaruhi pengikutnya merupakan faktor dominan yang menentukan keberhasilan suatu organisasi, karena kepemimpinan memiliki peran sebagai koordinator, motivator, dan katalis yang akan membawa organisasi pada puncak keberhasilan. Keefektifan pemimpin khususnya dipandang dengan ukuran tingkat pencapaian satu atau kombinasi tujuan. 
Dalam telah Perilaku Keorganisasian, khususnya teori yang mengatur hubungan antara pemimpin dan bawahan, populer diistilahkan dengan "Leader Member Exchange" atau "LMX". Yukl \& Becker (2006) menyebutkan bahwa "Teori Leader Member Exchange (LMX)" menguraikan peran membuat suatu proses hubungan antara seorang pemimpin dan bawahan dan hubungan pertukaran ini dikembangkan dari waktu ke waktu. Teori LMX dahulu disebut dengan "Vertical Dyad Linkage Theory" karena fokusnya pada proses pengaruh timbal balik yang terdiri atas seseorang yang mempunyai otoritas mengarahkan orang lain. Schaufeli et al., (2002) berpendapat bahwa pemahaman terhadap hubungan pertukaran yang terjadi diantara atasan bawahan menjadi bagian penting dalam memahami bagaimana proses kepemimpinan dan peningkatan kinerja. Meski demikian, masih terlihat sangat terbatasnya penelitian empiris yang dilakukan sehingga perlu dilakukan penelitian untuk mengetahui peran LMX terhadap kinerja SDM. Hasil penelitian menunjukkan/membuktikan adanya hubungan antara LMX dengan capaian kinerja, seperti: Rahmadalena \& Asmanita (2020) menyimpulkan LMX memiliki pengaruh terhadap kinerja organisasi. Dewi et al., (2019) menunjukkan hubungan positif antara LMX dan kinerja tugas. Sepdiningtyas (2016) membuktikan Leader-Member Exchange berpengaruh terhadap kinerja individual.

Menurut Liliweri (2014) setiap organisasi memiliki iklim yang berbeda-beda. Iklim organisasi pada konsep yang paling dasar adalah persepsi anggota organisasi (secara individual dan kelompok) dan mereka yang secara tetap berhubungan dengan organisasi mengenai apa yang ada atau terjadi di lingkungan internal organisasi secara rutin yang mempengaruhi sikap dan perilaku organisasi dan kinerja anggota organisasi yang kemudian menentukan kinerja organisasi.

Penelitian mengenai faktor-faktor yang mempengaruhi kinerja terkait dengan iklim organisasi banyak menarik minat peneliti dibidang manajemen, khususnya Manajemen Sumber Daya Manusia dan Perilaku Organisasi, diantaranya adalah penelitian yang dilakukan oleh Adeyemi (2008); Selamat et al., (2013); Suliman \& al Harethi (2013); Suandi et al., (2014) yang menemukan bahwa tinggi rendahnya kinerja pegawai dipengaruhi secara langsung oleh sehat atau tidaknya iklim organisasi yang ada pada organisasi.

Schaufeli et al., (2002) mendefinisikan work engagement sebagai kondisi psikologis terkait dengan sikap, perasaan, dan pikiran yang positif berkaitan dengan pekerjaan yang bercirikan semangat (vigor), dedikasi (dedication), dan kelarutan (absorption).

Teori Job Demand-Resources (JD-R) yang dikemukakan oleh Bakker \& Demerouti (2008) menjelaskan faktor-faktor yang dapat memunculkan work engagement adalah tuntutan pekerjaan (job demand) dan sumber daya dari pekerjaan (job resources), meliputi, aspek fisik, sosial dan organisasi. Sumber daya dari pekerjaan dapat menurunkan tuntutan pekerjaan yang berhubungan dengan fisiologis dan psikologis, membantu mencapai target dan tujuan pekerjaan, serta dapat menstimulasi pertumbuhan, pembelajaran dan pengembangan pribadi karyawan.

Beberapa hasil penelitian menunjukkan bahwa work engagement merupakan salah satu kunci untuk menunjukkan performa kerja yang lebih baik. Bakker \& Demerouti 
(2008) menemukan bahwa work engagement dapat meningkatkan kinerja karyawan. Ditegaskan, mengingat dampak positif tersebut, maka perlu diketahui hal apa saja yang dapat memprediksi terjadinya work engagement agar tujuan dan kinerja organisasi dapat tercapai.

Berdasarkan kajian teoritis, maka kerangka konseptual penelitian ini sebagaimana digambarkan pada Gambar 1.

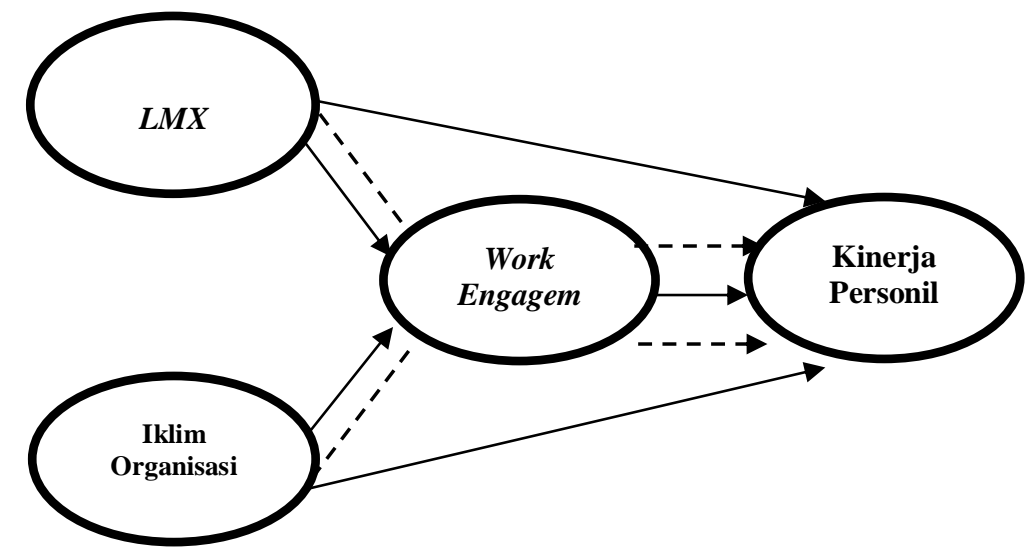

Gambar 1. Kerangka Konseptual Penelitian

Ket:

Direct Effect

Indirect Effect

\section{Metode Penelitian}

\subsection{Metode Pengumpulan Data}

Jenis penelitian ini merupakan explanatory research yang bertujuan untuk menjelaskan hubungan sebab akibat. Subjek atau unit analisis penelitian ini adalah personel militer Depo Pemeliharaan 30 Lanud Abdulrachman Saleh Malang, mencakup Tamtama, Bintara, dan Perwira yang berjumlah 250 personel. Teknik penarikan sampel dalam penelitian ini mempergunakan "Proportional Random Sampling" (Sugiyono, 2014). Ukuran sampel ditentukan dengan rumus Slovin, dan diperoleh jumlah sampel yang diwakili oleh 100 responden, dimana level Tamtama sebanyak 24 responden, level Bintara sebanyak 61 responden, dan level Perwira sebanyak 15 responden.

Survei dilakukan dengan memberikan kuesioner kepada seluruh responden untuk mendapatkan variabel yang terkait dengan Leader Member Exchange/LMX (X1) yang diukur melalui indikator, yaitu: kontribusi, kesetiaan, dayatarik, dan penghargaan professional (Liden \& Maslyn, 1998). Iklim Organisasi (X2) yang diukur melalui indikator, yaitu: struktur organisasi, standar-standar, tanggung jawab, penghargaan, dukungan, dan komitmen (Tweddell et al., 2002). Work Engagement (Y) yang diukur melalui indikator, yaitu: semangat, dedikasi, dan penghayatan (Schaufeli et al., 2002). Kinerja Personil (Z) yang diukur melalui indikator sebagaimana Keputusan Kepala Staf Angkatan Udara Nomor: Kep/646/XII/2012 tanggal 14 Desember 2012 mencakup: efisiensi, efektivitas, dan kualitas. Variabel data diperoleh dalam bentuk skala likert 
ordinal, dalam lima jawaban termasuk sangat setuju, setuju, kurang setuju, tidak setuju, dan sangat tidak setuju. Teknik analisis yang digunakan yaitu tekhnik Struktural Equation Modelling (SEM) dengan penggunaan Partial Least Squares (PLS-SEM) melalui bantuan software SmartPLS.

Pengujian instrumen penelitian dilakukan dengan model pengukuran (outer model) untuk menentukan spesifikasi hubungan antara variabel laten dengan variabel manifesnya, pengujian ini meliputi:

1. Convergent validity;

2. Discriminat validity, dan;

3. Composite reliability.

\section{1) Convergent Validity}

Pengujian validitas untuk indikator reflektif menggunakan korelasi antara skor item dengan skor konstruknya. Pengukuran dengan indikator reflektif menunjukkan adanya perubahan pada suatu indikator dalam suatu konstruk jika indikator lain pada konstruk yang sama berubah (atau dikeluarkan dari model). Indikator reflektif cocok digunakan untuk mengukur persepsi sehingga penelitian ini menggunakan indikator reflektif.

Convergent validity dari measurement model dengan indikator reflektif dapat dilihat dari korelasi antara score item dengan score konstruknya. Indikator individu dianggap reliabel jika memiliki nilai korelasi diatas 0.70 . Namun demikian pada riset tahap pengembangan skala, loading 0.50 sampai 0.60 masih dapat diterima (Ghozali, 2014). Berdasarkan pada result for outer loading (tabel 1) maka seluruh indikator memiliki loading di atas 0.60 dan signifikan.

\section{Tabel 1}

Result For Outer Loading

\begin{tabular}{|c|c|c|c|c|}
\hline Item & $\begin{array}{c}\text { LMX } \\
\text { (X1) }\end{array}$ & $\begin{array}{c}\text { Iklim } \\
\text { Organisasi } \\
(\mathbf{X 2})\end{array}$ & $\begin{array}{c}\text { Work } \\
\text { Engagement } \\
(\mathbf{Y})\end{array}$ & $\begin{array}{c}\text { Kinerja } \\
(\mathbf{Z})\end{array}$ \\
\hline $\mathrm{X} 1.1 .1$ & 0.831 & & & \\
\hline $\mathrm{X} 1.1 .2$ & 0.834 & & & \\
\hline $\mathrm{X} 1.1 .3$ & 0.858 & & & \\
\hline $\mathrm{X} 1.2 .1$ & 0.818 & & & \\
\hline $\mathrm{X} 1.2 .2$ & 0.873 & & & \\
\hline $\mathrm{X} 1.2 .3$ & 0.855 & & & \\
\hline $\mathrm{X} 1.3 .1$ & 0.843 & & & \\
\hline $\mathrm{X} 1.3 .2$ & 0.862 & & & \\
\hline $\mathrm{X} 1.3 .3$ & 0.791 & & & \\
\hline $\mathrm{X} 1.4 .1$ & 0.888 & & & \\
\hline $\mathrm{X} 1.4 .2$ & 0.882 & & & \\
\hline $\mathrm{X} 1.4 .3$ & 0.768 & & & \\
\hline $\mathrm{X} 2.1 .1$ & & 0.892 & & \\
\hline $\mathrm{X} 2.1 .2$ & & 0.883 & & \\
\hline $\mathrm{X} 2.2 .1$ & & 0.913 & & \\
\hline $\mathrm{X} 2.2 .2$ & & 0.920 & & \\
\hline $\mathrm{X} 2.3 .1$ & & 0.878 & & \\
\hline $\mathrm{X} 2.3 .2$ & & 0.877 & & \\
\hline $\mathrm{X} 2.4 .1$ & & 0.905 & & \\
\hline $\mathrm{X} 2.4 .2$ & & 0.898 & & \\
\hline $\mathrm{X} 2.5 .1$ & & 0.929 & & \\
\hline $\mathrm{X} 2.5 .2$ & & 0.931 & & \\
\hline $\mathrm{X} 2.6 .1$ & & 0.886 & & \\
\hline $\mathrm{X} 2.6 .2$ & & & & \\
\hline $\mathrm{Y} 1.1 .1$ & & & & \\
\hline & & & & \\
\hline
\end{tabular}




\begin{tabular}{|c|c|c|c|c|}
\hline Item & $\begin{array}{r}L M X \\
(\mathrm{X} 1)\end{array}$ & $\begin{array}{c}\text { Iklim } \\
\text { Organisasi } \\
\text { (X2) } \\
\end{array}$ & $\begin{array}{c}\text { Work } \\
\text { Engagement } \\
\text { (Y) } \\
\end{array}$ & $\begin{array}{c}\text { Kinerja } \\
(\mathrm{Z})\end{array}$ \\
\hline Y1.1.2 & & & 0.911 & \\
\hline Y1.1.3 & & & 0.786 & \\
\hline Y1.1.4 & & & 0.798 & \\
\hline Y1.2.1 & & & 0.807 & \\
\hline Y1.2.2 & & & 0.837 & \\
\hline Y1.2.3 & & & 0.927 & \\
\hline Y1.2.4 & & & 0.906 & \\
\hline Y1.3.1 & & & 0.771 & \\
\hline $\mathrm{Y} 1.3 .2$ & & & 0.820 & \\
\hline Y1.3.3 & & & 0.775 & \\
\hline Y1.3.4 & & & 0.790 & \\
\hline Z1.1.1 & & & & 0.650 \\
\hline Z1.1.2 & & & & 0.808 \\
\hline Z1.1.3 & & & & 0.798 \\
\hline Z1.1.4 & & & & 0.824 \\
\hline Z1.2.1 & & & & 0.844 \\
\hline Z1.2.2 & & & & 0.823 \\
\hline $\mathrm{Z} 1.2 .3$ & & & & 0.851 \\
\hline Z1.2.4 & & & & 0.806 \\
\hline Z1.3.1 & & & & 0.840 \\
\hline Z1.3.2 & & & & 0.820 \\
\hline Z1.3.3 & & & & 0.779 \\
\hline Z1.3.4 & & & & 0.788 \\
\hline
\end{tabular}

Sumber: Data kuesioner diolah, 2021

\section{2) Discriminat Validity}

Discriminat validity dari model pengukuran dengan indikator reflektif dinilai berdasarkan cross loading pengukuran dengan konstruk.

Tabel 2

Hasil Uji Cross Loading

\begin{tabular}{|c|c|c|c|c|}
\hline Item & $\begin{array}{c}\text { LMX } \\
(\mathbf{X 1})\end{array}$ & $\begin{array}{c}\text { Iklim } \\
\text { Organisasi } \\
(\mathbf{X 2})\end{array}$ & $\begin{array}{c}\text { Work } \\
\text { Engagement } \\
(\mathbf{Y})\end{array}$ & $\begin{array}{c}\text { Kinerja } \\
(\mathbf{Z})\end{array}$ \\
\hline $\mathrm{X} 1.1 .1$ & 0.708 & 0.677 & 0.623 & 0.608 \\
\hline $\mathrm{X} 1.1 .2$ & 0.737 & 0.626 & 0.572 & 0.481 \\
\hline $\mathrm{X} 1.1 .3$ & 0.862 & 0.707 & 0.642 & 0.550 \\
\hline $\mathrm{X} 1.2 .1$ & 0.732 & 0.663 & 0.574 & 0.566 \\
\hline $\mathrm{X} 1.2 .2$ & 0.792 & 0.670 & 0.640 & 0.609 \\
\hline $\mathrm{X} 1.2 .3$ & 0.730 & 0.540 & 0.537 & 0.448 \\
\hline $\mathrm{X} 1.3 .1$ & 0.753 & 0.723 & 0.683 & 0.723 \\
\hline $\mathrm{X} 1.3 .2$ & 0.792 & 0.670 & 0.611 & 0.597 \\
\hline $\mathrm{X} 1.3 .3$ & 0.718 & 0.642 & 0.675 & 0.590 \\
\hline $\mathrm{X} 1.4 .1$ & 0.816 & 0.694 & 0.734 & 0.634 \\
\hline $\mathrm{X} 1.4 .2$ & 0.806 & 0.660 & 0.719 & 0.611 \\
\hline $\mathrm{X} 1.4 .3$ & 0.700 & 0.659 & 0.697 & 0.577 \\
\hline $\mathrm{X} 2.1 .1$ & 0.717 & 0.771 & 0.736 & 0.588 \\
\hline $\mathrm{X} 2.1 .2$ & 0.666 & 0.742 & 0.586 & 0.493 \\
\hline $\mathrm{X} 2.2 .1$ & 0.643 & 0.744 & 0.666 & 0.600 \\
\hline $\mathrm{X} 2.2 .2$ & 0.773 & 0.812 & 0.776 & 0.596 \\
\hline $\mathrm{X} 2.3 .1$ & 0.673 & 0.742 & 0.633 & 0.662 \\
\hline $\mathrm{X} 2.3 .2$ & 0.628 & 0.742 & 0.691 & 0.581 \\
\hline $\mathrm{X} 2.4 .1$ & 0.648 & 0.790 & 0.666 & 0.659 \\
\hline $\mathrm{X} 2.4 .2$ & 0.668 & 0.764 & 0.703 & 0.695 \\
\hline $\mathrm{X} 2.5 .1$ & 0.650 & 0.775 & 0.596 & 0.616 \\
\hline $\mathrm{X} 2.5 .2$ & 0.604 & 0.789 & 0.634 & 0.697 \\
\hline $\mathrm{X} 2.6 .1$ & 0.677 & 0.730 & 0.658 & 0.593 \\
\hline $\mathrm{X} 2.6 .2$ & 0.532 & 0.707 & 0.546 & 0.588 \\
\hline & & & & \\
\hline
\end{tabular}




\begin{tabular}{|c|c|c|c|c|}
\hline Item & $\begin{array}{c}\text { LMX } \\
(\mathbf{X 1})\end{array}$ & $\begin{array}{c}\text { Iklim } \\
\text { Organisasi } \\
(\mathbf{X 2})\end{array}$ & $\begin{array}{c}\text { Work } \\
\text { Engagement } \\
(\mathbf{Y})\end{array}$ & $\begin{array}{c}\text { Kinerja } \\
(\mathbf{Z})\end{array}$ \\
\hline Y1.1.1 & 0.627 & 0.666 & 0.776 & 0.622 \\
\hline Y1.1.2 & 0.623 & 0.690 & 0.785 & 0.705 \\
\hline Y1.1.3 & 0.672 & 0.682 & 0.721 & 0.692 \\
\hline Y1.1.4 & 0.615 & 0.703 & 0.801 & 0.637 \\
\hline Y1.2.1 & 0.624 & 0.661 & 0.700 & 0.534 \\
\hline Y1.2.2 & 0.689 & 0.762 & 0.818 & 0.733 \\
\hline Y1.2.3 & 0.811 & 0.755 & 0.845 & 0.681 \\
\hline Y1.2.4 & 0.773 & 0.777 & 0.882 & 0.746 \\
\hline Y1.3.1 & 0.722 & 0.733 & 0.828 & 0.652 \\
\hline Y1.3.2 & 0.523 & 0.524 & 0.676 & 0.566 \\
\hline Y1.3.3 & 0.543 & 0.472 & 0.603 & 0.531 \\
\hline Y1.3.4 & 0.385 & 0.400 & 0.606 & 0.487 \\
\hline Z1.1.1 & 0.439 & 0.412 & 0.525 & 0.573 \\
\hline Z1.1.2 & 0.542 & 0.585 & 0.615 & 0.747 \\
\hline Z1.1.3 & 0.752 & 0.751 & 0.671 & 0.792 \\
\hline Z1.1.4 & 0.496 & 0.541 & 0.555 & 0.772 \\
\hline Z1.2.1 & 0.523 & 0.615 & 0.666 & 0.800 \\
\hline Z1.2.2 & 0.591 & 0.601 & 0.673 & 0.765 \\
\hline Z1.2.3 & 0.733 & 0.733 & 0.764 & 0.797 \\
\hline Z1.2.4 & 0.549 & 0.594 & 0.632 & 0.768 \\
\hline Z1.3.1 & 0.618 & 0.688 & 0.703 & 0.785 \\
\hline Z1.3.2 & 0.768 & 0.768 & 0.696 & 0.808 \\
\hline Z1.3.3 & 0.497 & 0.523 & 0.541 & 0.766 \\
\hline Z1.3.4 & 0.507 & 0.610 & 0.654 & 0.797 \\
\hline
\end{tabular}

Sumber: Data kuesioner diolah, 2021

Jika korelasi konstruk dengan item pengukuran lebih besar daripada ukuran konstruk lainnya, maka hal itu menunjukkan bahwa konstruk laten memprediksi ukuran pada blok mereka lebih baik daripada ukuran pada blok lainnya. Pada tabel diatas, terlihat bahwa nilai cross loading untuk setiap indikator (kolom tebal) lebih tinggi jika dibandingkan dengan korelasi indikator dengan variabel laten yang lainnya, sehingga variabel laten memiliki discriminant validity yang memadai.

Cara lain mengukur discriminant validity adalah melihat nilai average variance extracted (AVE). Nilai yang disarankan adalah diatas 0.5. Berikut adalah hasil cross loading dalam penelitian yang dihasilkan pada tabel 3 .

\section{Tabel 3}

Average Variance Extracted (AVE)

\begin{tabular}{|l|c|}
\hline \multicolumn{1}{|c|}{ Konstruk } & AVE \\
\hline Leader Member Exchange (X1) & 0.579 \\
\hline Iklim Organisasi (X2) & 0.572 \\
\hline Work Engagement (Y) & 0.575 \\
\hline Kinerja (Z) & 0.588 \\
\hline
\end{tabular}

Sumber: Data kuesioner diolah, 2021

Tabel 3, memberikan nilai AVE di atas 0.5 untuk semua konstruk, Leader Member Exchange $(\mathrm{X} 1)=0.579$, Iklim Organisasi $(\mathrm{X} 2)=0.572$, Work Engagement $(\mathrm{Y})=0.575$, dan Kinerja $(Z)=0.588$. Hal ini berarti semua konstruk memiliki discriminant validity yang tinggi. 


\section{3) Composite Reliability}

Pengujian selanjutnya adalah composite reliability dari blok indikator yang mengukur konstruk. Suatu konstruk dikatakan reliable jika nilai composite reliability diatas 0.60 (Ghozali, 2014).

Tabel 4

Composite Reliability

\begin{tabular}{|l|c|}
\hline \multicolumn{1}{|c|}{ Konstruk } & Composite Reliability \\
\hline Leader Member Exchange (X1) & 0.943 \\
\hline Iklim Organisasi (X2) & 0.941 \\
\hline Work Engagement (Y) & 0.941 \\
\hline Kinerja (Z) & 0.944 \\
\hline
\end{tabular}

Sumber: Data kuesioner diolah, 2021

Berdasarkan tabel 4, menunjukkan hasil composite reliablity yang memuaskan yaitu Leader Member Exchange $(X 1)=0.943$, Iklim Organisasi $(X 2)=0.941$, Work Engagement $(\mathrm{Y})=0.941$, dan Kinerja $(\mathrm{Z})=0.944$. Jadi dapat disimpulkan bahwa masingmasing konstruk memiliki reliabilitas yang tinggi. Hal ini dapat dilihat dari nilai composite reliability seluruh konstruk lebih besar dari 0.90. Hasil uji reliabilitas juga bisa diperkuat dengan cronbach's alpha di mana output SmartPLS pada tabel 5.

\section{Tabel 5}

\section{Cronbach's Alpha}

\begin{tabular}{|l|c|}
\hline \multicolumn{1}{|c|}{ Konstruk } & Cronbach's Alpha \\
\hline Leader Member Exchange (X1) & 0.933 \\
\hline Iklim Organisasi (X2) & 0.932 \\
\hline Work Engagement (Y) & 0.931 \\
\hline Kinerja (Z) & 0.935 \\
\hline
\end{tabular}

Sumber: Data kuesioner diolah, 2021

Nilai yang disarankan adalah diatas 0.6 dan pada tabel diatas menunjukkan bahwa nilai cronbach's alpha untuk semua konstruk berada diatas 0.8 .

\section{Hasil dan Pembahasan}

\subsection{Hypothesis Test}

Berdasarkan karakteristik diatas rata-rata responden: Usia 41-50 tahun (34\%), Masa Kerja 5-15 tahun (39\%), Pendidikan Terakhir Sarjana (62\%), dan Penghasilan 3-5 juta (39\%). Berdasarkan pada result for outer loading seluruh indikator memiliki loading diatas 0.60 dan signifikan, yakni: 0,650-0,931. Nilai AVE diatas 0.5 untuk semua konstruk, Leader Member Exchange $(\mathrm{X} 1)=0.579$, Iklim Organisasi $(\mathrm{X} 2)=0.572$, Work Engagement $(\mathrm{Y})$ $=0.575$, dan Kinerja $(Z)=0.588$. Hal ini berarti semua konstruk memiliki discriminat validity yang tinggi. Hasil composite reliablity memuaskan, yaitu Leader Member Exchange $(\mathrm{X} 1)=0.943$, Iklim Organisasi $(\mathrm{X} 2)=0.941$, Work Engagement $(\mathrm{Y})=0.941$, dan Kinerja $(Z)=0.944$. Jadi dapat disimpulkan bahwa masing-masing konstruk memiliki reliabilitas yang tinggi. Hal ini dapat dilihat dari nilai composite reliability seluruh konstruk lebih besar dari 0.90. Nilai cronbach's alpha untuk semua kontruk berada diatas 
0.8, dimana: Leader Member Exchange $(X 1)=0.933$, Iklim Organisasi $(X 2)=0.932$, Work Engagement $(\mathrm{Y})=0.931$, dan Kinerja $(\mathrm{Z})=0.935$.

Secara keseluruhan nilai rata-rata skor untuk Leader Member Exchange (X1) adalah sebesar 4.33, dan berdasarkan kategori nilai indeks sebelumnya, masuk dalam kategori sangat baik. Iklim Organisasi (X2) adalah sebesar 4.30, masuk dalam kategori sangat baik. Secara keseluruhan nilai rata-rata skor untuk Work Engagement (Y) adalah sebesar 4.32, masuk dalam kategori sangat tinggi. Kinerja (Z) adalah sebesar 4.18, masuk dalam kategori tinggi.

Pengujian model struktural (inner model) dapat dilihat dari nilai $R$-Square untuk setiap variabel endogen sebagai kekuatan prediksi dari model struktural. Perubahan nilai $R$-Square dapat digunakan untuk menjelaskan pengaruh variabel laten eksogen tertentu terhadap variabel laten endogen. Work Engagement (Y) yang diperoleh adalah sebesar 0.789 atau 78.9\%. Hasil tersebut menunjukan bahwa Leader Member Exchange (X1) dan Iklim Organisasi (X2) secara bersama-sama memberikan pengaruh sebesar $78.9 \%$ terhadap Work Engagement (Y), sedangkan sebanyak (1-R-Square) $21.1 \%$ sisanya merupakan besar kontribusi pengaruh yang diberikan oleh faktor lain yang tidak diteliti.

Selanjutnya, variabel laten endogen Kinerja (Z) yang diperoleh adalah sebesar 0.733 atau 73.3\%. Hasil tersebut menunjukan bahwa Leader Member Exchange (X1), Iklim Organisasi (X2) dan Work Engagement (Y) secara bersama-sama memberikan pengaruh sebesar $73.3 \%$ terhadap Kinerja (Z), sedangkan sebanyak (1-R-Square) $26.7 \%$ sisanya merupakan besar kontribusi pengaruh yang diberikan oleh faktor lain yang tidak diteliti.

Disamping $R$-Square, pengujian model struktural (inner model) juga dapat dilihat dari nilai $Q$-Square. Adapun hasil perhitungan nilai $Q$-Square adalah sebagai berikut:

$$
\begin{aligned}
Q \text {-Square } & =1-\left[\left(1-\mathrm{R}^{2}\right) \times\left(1-\mathrm{R}^{2}{ }_{2}\right)\right] \\
& =1-[(1-0.789) \times(1-0.733)] \\
& =1-(0.211 \times 0.267) \\
& =1-0.057 \\
& =0.943
\end{aligned}
$$

Berdasarkan hasil perhitungan diatas, diperoleh nilai Q-Square sebesar 0.943. Hal ini menunjukkan besarnya keragaman dari data penelitian yang dapat dijelaskan oleh model penelitian adalah sebesar 94.3\%, sedangkan sisanya sebesar 5.7\% dijelaskan oleh faktor lain yang berada diluar model penelitian ini.

Uji hipotesis pada penelitian ini dilakukan dengan melihat nilai $P$-Values. Hipotesis penelitian dapat dinyatakan diterima apabila nilai $P$-Values $<0.05$. Dapat diketahui bahwa dari 7 hipotesis yang diajukan dalam penelitian ini, hipotesis H1, H2, H4, H5, H6 dan $\mathrm{H} 7$ dapat diterima karena masing-masing pengaruh yang ditunjukkan memiliki nilai $P$-Values $<0.05$, sedangkan H3 ditolak karena memiliki nilai $P$-Values $>0.05$. 
Tabel 6.

Path Coefficients

\begin{tabular}{|l|c|c|c|}
\hline \multicolumn{1}{|c|}{ Path } & $\begin{array}{c}\text { Original } \\
\text { Sample }\end{array}$ & $\begin{array}{c}\text { T- } \\
\text { Statistics }\end{array}$ & P-Values \\
\hline $\begin{array}{l}\text { Leader Member Exchange (X1) } \rightarrow \text { Work } \\
\text { Engagement (Y) }\end{array}$ & 0.356 & 3.892 & 0.000 \\
\hline $\begin{array}{l}\text { Iklim Organisasi (X2) } \rightarrow \text { Work Engagement (Y) } \\
\text { a }\end{array}$ & 0.560 & 5.769 & 0.000 \\
\hline Leader Member Exchange (X1) $\rightarrow$ Kinerja (Z) & 0.055 & 0.455 & 0.649 \\
\hline Iklim Organisasi (X2) $\rightarrow$ Kinerja (Z) c & 0.309 & 3.860 & 0.000 \\
\hline Work Engagement (Y) $\rightarrow$ Kinerja (Z) b & 0.523 & 3.314 & 0.001 \\
\hline $\begin{array}{l}\text { Leader Member Exchange (X1) } \rightarrow \text { Work } \\
\text { Engagement (Y) } \rightarrow \text { Kinerja (Z) }\end{array}$ & 0.187 & 2.342 & 0.020 \\
\hline $\begin{array}{l}\text { Iklim Organisasi (X2) } \rightarrow \text { Work Engagement } \\
(Y) \rightarrow \text { Kinerja (Z) }\end{array}$ & 0.293 & 3.137 & 0.002 \\
\hline
\end{tabular}

Sumber: Data primer diolah (2021)

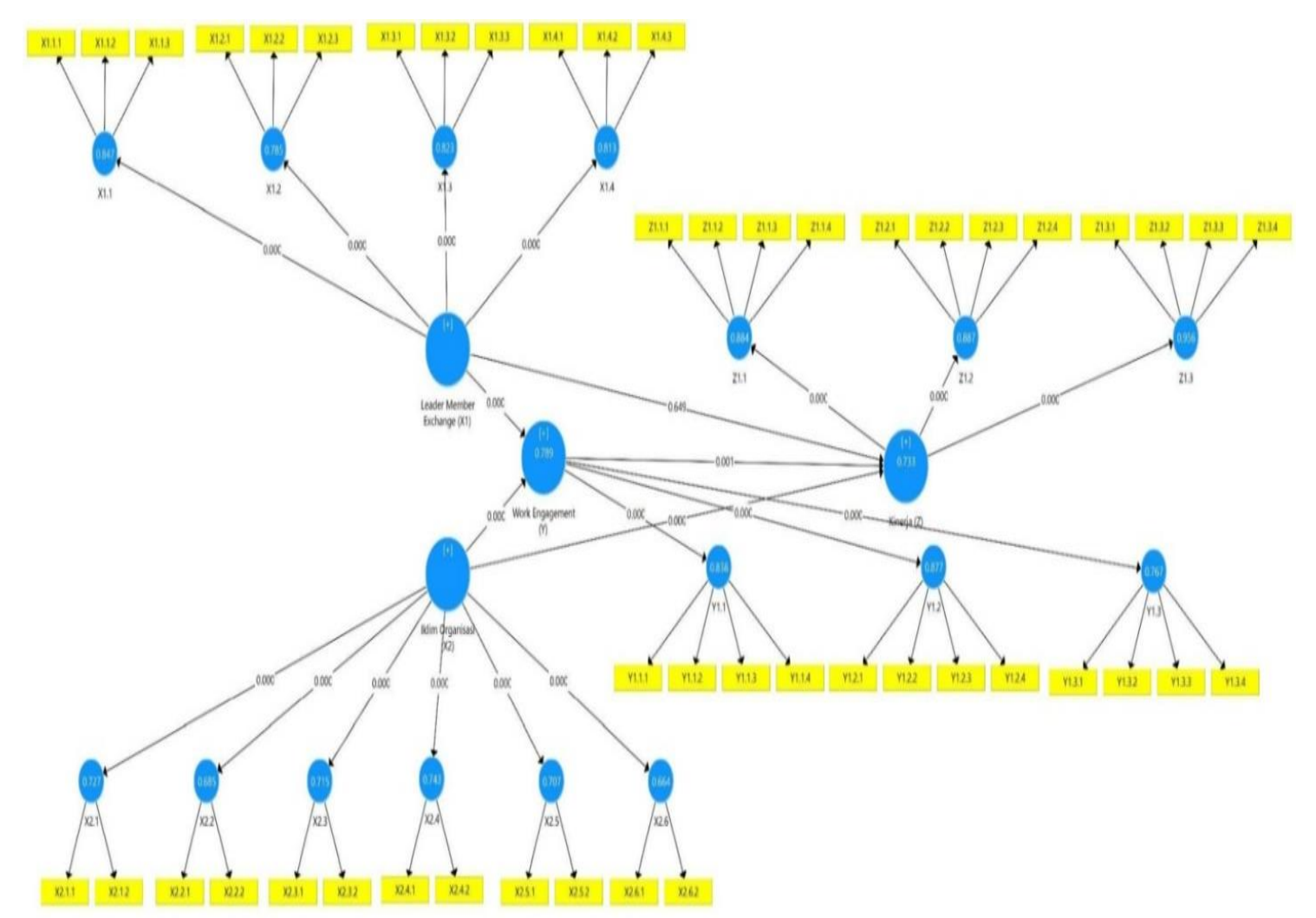

Gambar 1. Inner Model

Tabel 7.

Ringkasan Hasil Uji Hipotesis

\begin{tabular}{|c|l|c|c|}
\hline Hipotesis & \multicolumn{1}{|c|}{ Path } & P-Values & Kesimpulan \\
\hline H1 & $\begin{array}{l}\text { Leader Member Exchange (X1) } \rightarrow \text { Work } \\
\text { Engagement (Y) }\end{array}$ & 0.000 & Diterima \\
\hline H2 & Iklim Organisasi (X2) $\rightarrow$ Work Engagement $(\mathrm{Y})$ & 0.000 & Diterima \\
\hline H3 & Leader Member Exchange (X1) $\rightarrow$ Kinerja (Z) & 0.649 & Ditolak \\
\hline
\end{tabular}




\begin{tabular}{|c|l|c|c|}
\hline Hipotesis & \multicolumn{1}{|c|}{ Path } & P-Values & Kesimpulan \\
\hline H4 & Iklim Organisasi (X2) $\rightarrow$ Kinerja (Z) & 0.000 & Diterima \\
\hline H5 & Work Engagement $(\mathrm{Y}) \rightarrow$ Kinerja (Z) & 0.001 & Diterima \\
\hline H6 & $\begin{array}{l}\text { Leader Member Exchange (X1) } \rightarrow \text { Work } \\
\text { Engagement }(\mathrm{Y}) \rightarrow \text { Kinerja }(\mathrm{Z})\end{array}$ & 0.020 & Diterima \\
\hline H7 & $\begin{array}{l}\text { Iklim Organisasi (X2) } \rightarrow \text { Work Engagement } \\
(\mathrm{Y}) \rightarrow \text { Kinerja }(\mathrm{Z})\end{array}$ & 0.002 & Diterima \\
\hline
\end{tabular}

Sumber: Data primer diolah, 2021

\subsection{Pembahasan}

\subsubsection{Pengaruh Leader Member Exchange terhadap Work Engagement}

Dari hasil analisis deskriptif diketahui secara keseluruhan nilai rata-rata skor untuk Leader Member Exchange adalah sebesar 4.33, dan berdasarkan kategori nilai indeks sebelumnya, masuk dalam kategori sangat baik. Hasil tersebut menunjukkan bahwa kualitas hubungan pertukaran interpersonal antara leader dan anggotanya di Depo Pemeliharaan 30 Lanud Abdulrachman Saleh Malang sudah sangat baik. Kemudian, secara keseluruhan nilai rata-rata skor untuk Work Engagement adalah sebesar 4.32, dan berdasarkan kategori nilai indeks sebelumnya, masuk dalam kategori sangat tinggi. Hasil tersebut menunjukan bahwa kondisi psikologis terkait dengan sikap, perasaan, dan pikiran yang positif berkaitan dengan pekerjaan yang bercirikan semangat (vigor), dedikasi (dedication), dan kelarutan (absorption) di Depo Pemeliharaan 30 Lanud Abdulrachman Saleh Malang sudah sangat tinggi.

Begitu juga dengan hasil uji hipotesis, diketahui bahwa Leader Member Exchange yang semakin baik mampu meningkatkan Work Engagement. Hal tersebut sesuai dengan hasil penelitian terdahulu Justina et al., (2019), bahwa LMX berhubungan positif serta memprediksi work engagement secara signifikan. Kemudian juga sesuai dengan penelitian terdahulu lainnya Dewi et al., (2019), dimana hasil penelitian menyebutkan LMX mempengaruhi secara langsung dan positif signifikan terhadap work engagement.

Pemimpin dapat memengaruhi lingkungan kerja karyawan sehingga secara tidak langsung memengaruhi kesejahteraan karyawan dan kinerjanya Bakker \& Demerouti (2008). Hubungan atasan-bawahan menjadi sangat penting pada pekerjaan. Atasan atau pemimpin dalam bekerja menjalankan berbagai fungsi manajerial dari perencanaan, pengorganisasian, penggerak, dan pengawasan. Tugas-tugas manajerial tersebut tidak dapat dicapai hanya oleh pimpinan seorang diri, tetapi dengan menggerakkan orang-orang yang dipimpinnya. Kualitas hubungan atasan dan bawahan mempengaruhi persepsi, sikap dan perilaku, baik atasan maupun bawahan yang memiliki hubungan tersebut. Teori mengenai hubungan antara pemimpin dengan karyawan ini disebut dengan Leader Member Exchange (LMX), yaitu pemimpin membangun suatu tipe hubungan timbal balik yang berbeda-beda terhadap para karyawan yang ada (Schaufeli et al., 2002).

Teori LMX lebih jauh menjelaskan bahwa karyawan yang mengalami hubungan LMX berkualitas rendah tidak mungkin berkontribusi melampaui upaya minimal yang dibutuhkan dalam bekerja, sedangkan karyawan yang mengalami hubungan LMX berkualitas tinggi cenderung berkontribusi melampaui persyaratan minimum pekerjaan. 
Kecenderungan perilaku kerja yang positif karena adanya perasaan bersama, kesetiaan, komitmen, dukungan, dan kepercayaan, yang dapat meningkat dari waktu ke waktu (Liden \& Maslyn, 1998). Organisasi perlu mengetahui bagaimana interaksi atasan dan bawahan dapat meningkatkan work engagement untuk meningkatkan performa kerja, sehingga mencapai keunggulan organisasi. 


\subsubsection{Pengaruh Iklim Organisasi terhadap Work Engagement}

Dari hasil analisis deskriptif diketahui secara keseluruhan nilai rata-rata skor untuk Iklim Organisasi adalah sebesar 4.30, dan berdasarkan kategori nilai indeks sebelumnya, masuk dalam kategori sangat baik. Hasil tersebut menunjukan bahwa kualitas lingkungan internal organisasi yang secara relatif terus berlangsung, dialami oleh anggota organisasi, mempengaruhi perilaku mereka dan dapat dilukiskan dalam pengertian satu set karakteristik atau sifat organisasi di Depo Pemeliharaan 30 Lanud Abdulrachman Saleh Malang sudah sangat baik. Kemudian, secara keseluruhan nilai rata-rata skor untuk Work Engagement adalah sebesar 4.32, dan berdasarkan kategori nilai indeks sebelumnya, masuk dalam kategori sangat tinggi. Hasil tersebut menunjukan bahwa kondisi psikologis terkait dengan sikap, perasaan, dan pikiran yang positif berkaitan dengan pekerjaan yang bercirikan semangat (vigor), dedikasi (dedication), dan kelarutan (absorption) di Depo Pemeliharaan 30 Lanud Abdulrachman Saleh Malang sudah sangat tinggi.

Begitu juga dengan hasil uji hipotesis, diketahui bahwa Iklim Organisasi yang semakin baik mampu meningkatkan Work Engagement. Hal tersebut sesuai dengan hasil penelitian Abdillah et al., (2016) yang menyebutkan bahwa iklim organisasi berpengaruh positif dan signifikan terhadap work engagement. Begitu juga dengan hasil penelitian Putra et al., (2020) yang menunjukkan bahwa persepsi iklim organisasi berpengaruh positif dan signifikan terhadap employee engagement.

Pentingnya keberadaan sumber daya manusia, menuntut adanya karyawan dengan engagement yang tinggi. Oleh karena itu perusahaan membutuhkan karyawan yang aktif, memiliki inisiatif dan mempunyai tanggung jawab penuh terhadap kemajuan perusahaan. Selain itu karyawan juga harus engaged dengan perusahaan. Karena dengan engaged, karyawan diharapkan memiliki komitmen, keinginan berkontribusi dan memiliki rasa untuk terlibat dalam pekerjaan. Riset menunjukkan bahwa karyawan yang memiliki keterikatan dengan perusahaan merupakan karyawan yang lebih produktif.

Karyawan yang berkualitas menjadi tolak ukur setiap perusahaan agar nantinya dapat memberikan keuntungan besar pada perusahaan tersebut. Kualitas karyawan dapat dilihat dari seberapa besar kontribusi mereka dalam menjalankan pekerjaannya. Kontribusi akan didapatkan jika setiap karyawan memiliki engagement yang tinggi pada perusahaan. Jika semua karyawan yang bekerja tidak memiliki engagement yang tinggi maka, tujuan dari perusahaan tidak akan tercapai yang akhirnya perusahaan tersebut tidak mampu meraih kesuksesan. Salah satu kunci perusahaan yang sukses adalah saat perusahaan tersebut memiliki karyawan yang engaged terhadap pekerjaan maupun perusahaan.

Menurut Maslyn \& Uhl-Bien (2001) terdapat beberapa faktor yang mempengaruhi keterikatan kerja, yaitu pekerjaan itu sendiri, kepemimpinan, kesempatan, dan iklim organisasi. Iklim organisasi melibatkan semua aspek lingkungan sosial, seperti yang dirasakan oleh karyawan yang dapat mempengaruhi pekerjaannya. Kondisi lingkungan kerja yang baik jika karyawan dapat bekerja dan menyelesaikan tugasnya secara maksimal, aman, dan nyaman. Menurut Bakker (2011), work engagement dipengaruhi oleh personal resource dan job resource. Salah satu faktor yang memicu engagement 
mengacu pada aspek fisik, psikologis, sosial, atau organisasi dari pekerjaan yang dapat membantu untuk mencapai tujuan perusahaan serta mendorong adanya pertumbuhan, pembelajaran dan pengembangan pada diri karyawan.

\subsubsection{Pengaruh Leader Member Exchange terhadap Kinerja}

Dari hasil analisis deskriptif diketahui secara keseluruhan nilai rata-rata skor untuk Leader Member Exchange adalah sebesar 4.33, dan berdasarkan kategori nilai indeks sebelumnya, masuk dalam kategori sangat baik. Hasil tersebut menunjukkan bahwa kualitas hubungan pertukaran interpersonal antara leader dan anggotanya di Depo Pemeliharaan 30 Lanud Abdulrachman Saleh Malang sudah sangat baik. Kemudian, secara keseluruhan nilai rata-rata skor untuk Kinerja adalah sebesar 4.18, dan berdasarkan kategori nilai indeks sebelumnya, masuk dalam kategori tinggi. Hasil tersebut menunjukkan bahwa hasil yang dicapai oleh personel dalam pekerjaannya menurut kriteria tertentu yang berlaku untuk suatu pekerjaan di Depo Pemeliharaan 30 Lanud Abdulrachman Saleh Malang sudah tinggi.

Begitu juga dengan hasil uji hipotesis, diketahui Leader Member Exchange yang semakin baik tidak mampu meningkatkan kinerja. Hal tersebut tidak sesuai dengan hasil penelitian terdahulu Abdillah et al., (2016), bahwa LMX mempengaruhi secara positif signifikan terhadap kinerja. Kemudian juga tidak sesuai dengan Schaufeli et al., (2002), bahwa terdapat keterkaitan antara Leader-member Exchange (LMX) dengan Performance.

Sebenarnya dari segi pengaruh, maka terdapat pengaruh antara leader member exchange dengan kinerja. Hal tersebut dilihat dari nilai original sample sebesar positif 0.055, namun pengaruh tersebut secara statistik tidak signifikan. Ketidak signifikan pengaruh leader member exchange terhadap kinerja dimungkinkan karena indikator daya tarik yang belum optimal. Mengingat skor penilaian responden terhadap indikator daya tarik berada pada skala kategori "baik" dan belum mencapai "sangat baik" seperti indikator-indikator lainnya pada variabel leader member exchange. Dengan skor "tinggi" (mean=4.11) pada daya tarik tersebut memungkinkan leader member exchange belum mampu meningkatkan kinerja secara signifikan.

Menurut Schaufeli et al., (2002) dalam leader member exchange ditemukan perbedaan sikap yang diterima bawahan dari atasannya. Perbedaan itu membentuk kelompok terpisah yang menerangkan hubungan antara atasan dan bawahan yang disebut dengan in-group dan out-group. Pada in-group, bawahan lebih dipercaya, mendapatkan perhatian dalam porsi yang lebih besar dari atasan, dan mendapatkan hak-hak khusus. Bawahan yang tergabung dalam out-group mendapatkan waktu yang terbatas dari atasannya dan hubungan antara atasan dan bawahan berdasarkan pada hubungan formal yang biasanya dapat dilihat dari penggunaan bahasa pada saat berkomunikasi.

\subsubsection{Pengaruh Iklim Organisasi terhadap Kinerja}

Dari hasil analisis deskriptif diketahui secara keseluruhan nilai rata-rata skor untuk Iklim Organisasi adalah sebesar 4.30, dan berdasarkan kategori nilai indeks sebelumnya, masuk dalam kategori sangat baik. Hasil tersebut menunjukan bahwa kualitas lingkungan 
internal organisasi yang secara relatif terus berlangsung, dialami oleh anggota organisasi, mempengaruhi perilaku mereka dan dapat dilukiskan dalam pengertian satu set karakteristik atau sifat organisasi di Depo Pemeliharaan 30 Lanud Abdulrachman Saleh Malang sudah sangat baik. Kemudian, secara keseluruhan nilai rata-rata skor untuk Kinerja adalah sebesar 4.18, dan berdasarkan kategori nilai indeks sebelumnya, masuk dalam kategori tinggi. Hasil tersebut menunjukkan bahwa hasil yang dicapai oleh personel dalam pekerjaannya menurut kriteria tertentu yang berlaku untuk suatu pekerjaan di Depo Pemeliharaan 30 Lanud Abdulrachman Saleh Malang sudah tinggi.

Begitu juga dengan hasil uji hipotesis, diketahui bahwa iklim organisasi yang semakin baik mampu meningkatkan kinerja. Hal tersebut sesuai dengan hasil penelitian terdahulu Harris et al., (2014), yang menunjukkan iklim organisasi berpengaruh positif dan signifikan terhadap kinerja karyawan. Kemudian juga sesuai Shafarila \& Supardi (2016) yang menyimpulkan iklim organisasi berpengaruh positif dan signifikan terhadap kinerja karyawan.

Iklim organisasi merupakan serangkaian sifat lingkungan kerja yang dinilai langsung dan tidak langsung oleh karyawan yang dianggap menjadi kekuatan utama dalam mempengaruhi perilaku (Bakker \& Demerouti, 2008). Iklim organisasi berpengaruh terhadap motivasi, produktivitas kerja dan kepuasan kerja. Iklim organisasi mempengaruhi dengan cara membentuk harapan karyawan tentang konsekuensi yang akan timbul dari berbagai tindakan.

Iklim organisasi yang belum menunjang penampilan kerja yang produktif, penyediaan teknologi organisasi dan kondisi kerja (seperti kantor dan fasilitas lainnya) memadai, kemudian arus komunikasi yang tidak menunjang dalam arti jumlah maupun mutu, praktek pengambilan keputusan tidak sejalan disemua jenjang organisasi, dan disisi lain kesejahteraan pegawai masih belum dapat diperhatikan secara baik akan mengakibatkan rendahnya kepuasan kerja. Ditegaskan pula bahwa iklim organisasi berfungsi sebagai faktor pengukuh dalam proses belajar-mengajar bagi perilaku kerja, kinerja dan kepuasan kerja, sehingga semakin sesuai dan semakin sehat suatu iklim organisasi, akan semakin tinggi tingkat kinerja karyawan dalam suatu organisasi.

\subsubsection{Pengaruh Work Engagement terhadap Kinerja}

Dari hasil analisis deskriptif diketahui secara keseluruhan nilai rata-rata skor untuk Work Engagement adalah sebesar 4.32, dan berdasarkan kategori nilai indeks sebelumnya, masuk dalam kategori sangat tinggi. Hasil tersebut menunjukan bahwa kondisi psikologis terkait dengan sikap, perasaan, dan pikiran yang positif berkaitan dengan pekerjaan yang bercirikan semangat (vigor), dedikasi (dedication), dan kelarutan (absorption) di Depo Pemeliharaan 30 Lanud Abdulrachman Saleh Malang sudah sangat tinggi. Kemudian, secara keseluruhan nilai rata-rata skor untuk Kinerja adalah sebesar 4.18, dan berdasarkan kategori nilai indeks sebelumnya, masuk dalam kategori tinggi. Hasil tersebut menunjukkan bahwa hasil yang dicapai oleh personel dalam pekerjaannya menurut kriteria tertentu yang berlaku untuk suatu pekerjaan di Depo Pemeliharaan 30 Lanud Abdulrachman Saleh Malang sudah tinggi. 
Begitu juga dengan hasil uji hipotesis, diketahui bahwa Work Engagement yang semakin baik mampu meningkatkan kinerja. Hal tersebut sesuai dengan hasil penelitian terdahulu Astuti et al., (2016) bahwa Work Engagement berpengaruh terhadap kinerja. Begitu juga dengan Sepdiningtyas (2016), dimana Work engagement berpengaruh terhadap kinerja.

Kinerja dipengaruhi oleh faktor individu, faktor organisasi dan faktor psikologis. Konsep yang membahas sisi psikologis positif kaitannya manusia terhadap pekerjaanya, adalah engagement (Bakker, 2011). Salah satu bentuk engagement adalah work engagement yang dimaknai sebagai keadaan mental yang positif, memuaskan dan berkaitan dengan pekerjaan yang dicirikan dengan kekuatan, dedikasi dan pengabdian.

Bakker \& Demerouti (2008), pegawai yang memiliki work engagement yang lebih tinggi, akan cenderung lebih kreatif, lebih produktif dan mau untuk bekerja ekstra. Merujuk pada beberapa hasil penelitian dapat disimpulkan bahwa work engagement merupakan salah satu aspek yang penting ada bagi setiap pegawai dalam menyelesaikan pekerjaan mereka yang diyakini mampu meningkatkan kinerjanya.

\subsubsection{Pengaruh Leader Member Exchange terhadap Kinerja yang dimediasi Work Engagement}

Dari hasil analisis deskriptif diketahui secara keseluruhan nilai rata-rata skor untuk Leader Member Exchangeadalah sebesar 4.33, dan berdasarkan kategori nilai indeks sebelumnya, masuk dalam kategori sangat baik. Hasil tersebut menunjukan bahwa kualitas hubungan pertukaran interpersonal antara leader dan anggotanya di Depo Pemeliharaan 30 Lanud Abdulrachman Saleh Malang sudah sangat baik. Kemudian, secara keseluruhan nilai rata-rata skor untuk Work Engagement adalah sebesar 4.32, dan berdasarkan kategori nilai indeks sebelumnya, masuk dalam kategori sangattinggi. Hasil tersebut menunjukan bahwa kondisi psikologis terkait dengan sikap, perasaan, dan pikiran yang positif berkaitan dengan pekerjaan yang bercirikan semangat (vigor), dedikasi (dedication), dan kelarutan (absorption) di Depo Pemeliharaan 30 Lanud Abdulrachman Saleh Malang sudah sangat tinggi. Sementara itu, secara keseluruhan nilai rata-rata skor untuk Kinerja adalah sebesar 4.18, dan berdasarkan kategori nilai indeks sebelumnya, masuk dalam kategori tinggi. Hasil tersebut menunjukkan bahwa hasil yang dicapai oleh personel dalam pekerjaannya menurut kriteria tertentu yang berlaku untuk suatu pekerjaan di Depo Pemeliharaan 30 Lanud Abdulrachman Saleh Malang sudah tinggi.

Hasil uji hipotesis dalam penelitian ini menyebutkan bahwa Leader Member Exchangeyang semakin baik mampu meningkatkan kinerja yang dimediasi Work Engagement. Hal tersebut dikarenakan semua jalur dari jalur Leader Member Exchange $(\mathrm{X} 1) \rightarrow$ Work Engagement $(\mathrm{Y}) \rightarrow$ Kinerja $(\mathrm{Z})$ adalah signifikan. Dalam hal ini, jalur Leader Member Exchange $(\mathrm{X} 1) \rightarrow$ Work Engagement $(\mathrm{Y})$ adalah signifikan, begitu juga dengan jalur Work Engagement $(\mathrm{Y}) \rightarrow$ Kinerja $(\mathrm{Z})$ adalah signifikan. Karena kedua jalur adalah signifikan. Dapatlah dikatakan kalau hubungan mediasi tersebut juga signifikan.

Menurut Liden \& Maslyn (1998), suatu variabel disebut intervening (mediasi) jika variabel tersebut ikut mempengaruhi hubungan antara variabel independen dan variabel dependen. Untuk melihat apakah mediasi tersebut merupakan mediasi sempurna atau 
bukan, maka dapat dijelaskan menggunakan kriteria mediasi menurut Harris et al., (2014). Salah satu kriterianya adalah apabila a, b, dan c signifikan tetapi nilai koefisien langsung $\mathrm{c}<\mathrm{b}$, maka $\mathrm{Z}$ dinyatakan sebagai mediasi sebagian. Diperoleh nilai a (nilai original sample jalur Leader Member Exchange (X1) $\rightarrow$ Work Engagement (Y)) sebesar 0.356. Nilai b (nilai original sample jalur Work Engagement $(\mathrm{Y}) \rightarrow$ Kinerja $(\mathrm{Z})$ ) sebesar 0.523. Kemudian, nilai c (nilai original sample jalur Leader Member Exchange (X1) $\rightarrow$ Kinerja (Z)) sebesar 0.055. Karena $\mathrm{c}=0.055$ lebih kecil dari $\mathrm{b}=0.523$, maka mediasi dalam penelitian ini dinyatakan sebagai mediasi sebagian (partial mediation).

\subsubsection{Pengaruh Iklim Organisasi terhadap Kinerja yang dimediasi Work Engagement}

Dari hasil analisis deskriptif diketahui secara keseluruhan nilai rata-rata skor untuk Iklim Organisasi adalah sebesar 4.30, dan berdasarkan kategori nilai indeks sebelumnya, masuk dalam kategori sangat baik. Secara keseluruhan nilai rata-rata skor untuk Work Engagement adalah sebesar 4.32, dan berdasarkan kategori nilai indeks sebelumnya, masuk dalam kategori sangat tinggi. Secara keseluruhan nilai rata-rata skor untuk Kinerja adalah sebesar 4.18, dan berdasarkan kategori nilai indeks sebelumnya, masuk dalam kategori tinggi. Hasil tersebut menunjukkan bahwa hasil yang dicapai oleh personel dalam pekerjaannya menurut kriteria tertentu yang berlaku untuk suatu pekerjaan di Depo Pemeliharaan 30 Lanud Abdulrachman Saleh Malang sudah tinggi.

Hasil uji hipotesis dalam penelitian ini menyebutkan bahwa Iklim Organisasi yang semakin baik mampu meningkatkan kinerja yang dimediasi Work Engagement. Hal tersebut dikarenakan semua jalur dari jalur Iklim Organisasi (X2) $\rightarrow$ Work Engagement $(\mathrm{Y}) \rightarrow$ Kinerja $(\mathrm{Z})$ adalah signifikan. Dalam hal ini, jalur Iklim Organisasi $(\mathrm{X} 2) \rightarrow$ Work Engagement $(\mathrm{Y})$ adalah signifikan, begitu juga dengan jalur Work Engagement $(\mathrm{Y}) \rightarrow$ Kinerja (Z) adalah signifikan. Karena kedua jalur adalah signifikan, dapatlah dikatakan kalau hubungan mediasi tersebut juga signifikan. Hasil uji hipotesis menyebutkan bahwa Leader Member Exchange tidak signifikan terhadap kinerja. Begitu pula dengan Work Engagement yang hanya berperan sebagian sebagai variabel mediasi. Sehingga penting bagi Depo Pemeliharaan 30 Lanud Abdulrachman Saleh Malang untuk memperhatikan kedua variabel tersebut. Menurut Schaufeli et al., (2002) terdapat tiga domain menjadi dasar dalam membangun hubungan pada LMX yaitu respect, trust dan obligation. Hubungan antar atasan dan bawahan tidak dapat terbentuk tanpa adanya saling menghormati (respect) terhadap kemampuan orang lain, tanpa adanya rasa percaya yang timbal balik dengan yang lain, dan tidak memperkirakan bahwa pengaruh kewajiban akan berkembang menjadi suatu hubungan kerja.

Kemudian Liden \& Maslyn (1998), mengembangkan suatu skala multi dimensional yang dinamakan LMX-MDM. Skala ini mengukur LMX dari 4 dimensi yang berbeda: 1) Afeksi: Saling mempengaruhi satu sama lain antara atasan dan bawahan berdasarkan pada daya tarik interpersonal, tidak hanya dari nilai professional pekerja. Terjadinya suatu hubungan pribadi yang saling bermanfaat (misalnya persahabatan); 2) Loyalitas: Ekspresi dan ungkapan untuk mendukung penuh terhadap tujuan dan karakter pribadi anggota lainnya dalam hubungan timbal balik pimpinan dan bawahan. Loyalitasme libatkan 
kesetiaan kepada individu yang umumnya konsisten dari situasi ke situasi; 3) Kontribusi: persepsi tentang kegiatan yang berorientasi pada tugas ditingkat tertentu antara setiap anggota untuk mencapai tujuan bersama (eksplisit atau implisit). Penting dalam evaluasi orientasi kerja adalah sejauh mana anggota bawahan dari dyad (dua orang yang berupa kesatuan yang berinteraksi) menangani tanggung jawab dan menyelesaikan tugas-tugas yang melampaui deskripsi pekerjaan atau kontrak kerja, dan juga sejauh mana atasan memberikan sumber daya dan peluang untuk kegiatan tersebut, dan; 4) Penghormatan profesional: persepsi sejauh mana setiap hubungan timbal balik telah memliki dan membangun reputasi didalam atau luar organisasi. Persepsi ini mungkin didasarkan pada data historis mengenai orang tersebut, seperti: pengalaman pribadi dengan individu, komentar yang dibuat orang lain didalam atau luar organisasi, dan penghargaan atau pengakuan profesional lainnya yang dicapai. Jadi ada kemungkinan, persepsi tentang rasa hormat pada seseorang telah ada sebelum bekerja atau bertemu dengan seseorang tersebut.

Variabel kedua yang perlu diperhatikan adalah Work Engagement. Menurut Bakker \& Demerouti (2008) menemukan bahwa faktor-faktor yang mempengaruhi work engagement adalah sebagai berikut: 1) Job Resources (Sumber Pekerjaan); diasumsikan sebagai sesuatu yang positif terkait dengan work engagement seperti dukungan sosial dari rekan-rekan kerja dan atasan, performance feedback, keterampilan serta kesempatan untuk belajar. Job Resource juga mengacu pada aspek fisik, aspek sosial, atau organisasi dari pekerjaan yang memungkinkan karyawan dapat mengurangi tuntutan pekerjaan yang menguras secara fisik maupun psikologis (psychological cost), memungkinkan untuk mencapai suatu tujuan kerja serta menstimulasi karyawan dalam pertumbuhan, pembelajaran serta perkembangan secara personal. Job resource terdiri dari tiga dimensi Wulandari \& Ratnaningsih (2017) yaitu: a) Level Organisasi; megacu pada kesesuaian fasilitas-fasilitas fisik yang disediakan oleh organisasi misalnya seperti gaji, kesempatan belajar, pengembangan organisasi serta kesediaan informasi yang tersedia dalam organisasi. b) Level Interpersonal; mengacu pada komunikasi serta hubungan yang terjalin baik antara sesama rekan kerja maupun atasan serta iklim kelompok yang positif. c) Level Tugas; mengacu pada keikutsertaan dalam pengambilan keputusan, jenis pekerjaan serta pemahaman peran dalam lingkungan kerja. Berdasarkan ketiga dimensi job resource tersebut psychosocial safety climate (PSC) masuk ke dalam level organisasi. Hal ini dikarenakan PSC merupakan bentuk kebijakan, praktek dan prosedur yang dibentuk organisasi untuk menjaga kesehatan serta keselamatan karyawan secara psikologis (Bakker, 2011). 2) Salience of Job Resource; mengacu pada seberapa penting bagaimana karyawan memanfaatkan sumber daya pekerjaan ketika mereka dihadapkan dengan tuntutan pekerjaan yang tinggi. 3. Personal Resource; merupakan sumber daya pribadi yang dimiliki oleh karyawan yang mengacu pada evaluasi diri secara positif yang mengacu pada kemampuan seorang individu atau karyawan dalam mengontrol dan mempengaruhi keberhasilan lingkungan mereka. Evaluasi diri yang positif tersebut dapat memprediksi penetapan tujuan, motivasi, kinerja, kepuasan hidup dan kepuasan kerja, ambisi karir dan hasil lain yang diharapkan. 


\subsection{Simpulan}

Leader Member Exchange yang semakin baik mampu meningkatkan work engagement. Iklim organisasi yang semakin baik mampu meningkatkan work engagement. Leader Member Exchange yang semakin baik tidak mampu meningkatkan kinerja. Iklim Organisasi yang semakin baik mampu meningkatkan kinerja. Work engagement yang semakin baik mampu meningkatkan kinerja. Leader Member Exchange yang semakin baik mampu meningkatkan kinerja yang dimediasi work engagement. Iklim organisasi yang semakin baik mampu meningkatkan kinerja yang dimediasi work engagement personil Depo Pemeliharaan 30 Lanud Abdulrachman Saleh Malang.

Berdasarkan hasil penelitian ini, maka peneliti dapat memberikan saran untuk menyempurnakan penelitian-penelitian selanjutnya. Pertama, peneliti selanjutnya diharapkan untuk mencari faktor-faktor lain yang mempengaruhi kinerja, misalnya seperti karakteristik individu, dan organizational citizenship behavior, dan lainnya. Kedua, tempat pengambilan responden penelitian ini hanya terbatas pada lokasi tertentu, diharapkan dapat memperluas tempat peneltian sehingga dapat memperoleh hasil secara representatif dari berbagai karakteristik maupun tempat lainnya. Ketiga, bagi depo pemeliharaan 30 Lanud Abdulrachman Saleh Malang, masih ada beberapa indiktor dalam penelitian ini yang nilai skornya masih belum optimal, seperti Daya tarik (X1.3), Tanggung jawab (X2.3), Penghargaan (X2.4), Komitmen (X2.6), Penghayatan (Y1.3), dan Efisiensi (Z1.1). Untuk itu perlu dilakukan evaluasi ulang dan monitoring lebih lanjut terhadap indikator-indikator yang dimaksud.

Penelitian ini telah diusahakan dan dilaksanakan sesuai dengan prosedur ilmiah, namun demikian masih memiliki keterbatasan. Pertama, faktor-faktor yang mempengaruhi kinerja dalam penelitian ini hanya terdiri dari tiga variabel, yaitu: leader member exchange, iklim organisasi dan work engangement, sedangkan masih banyak faktor lain yang mempengaruhi kinerja. Kedua, adanya keterbatasan penelitian dengan menggunakan kuesioner yaitu terkadang jawaban yang diberikan oleh sampel tidak menunjukkan keadaan sesungguhnya.

\section{Referensi}

Abdillah, M. R., Anita, R., \& Anugerah, R. (2016). Dampak Iklim Organisasi Terhadap Stres Kerja dan Kinerja Karyawan. Jurnal Manajemen, 20(1), 121-141.

Adeyemi, T. O. (2008). Teachers Teaching Experience and Students Learning Outcomes in Secondary Schools in Ondo State, Nigeria. Educational Research and Reviews, 3(6), 204-212.

Apriani, U., Karo, K. K., Yuliana, F., Astika, F., Ridwan, R., Darmawan, D., Bustomi, B., \& Umar, H. (2019). Pengaruh Independensi Pengawasan Internal Terhadap Pencegahan Korupsi dengan Komitmen Organisasi Sebagai Variabel Moderasi (Studi Pada Mahkamah Agung RI). Prosiding Seminar Nasional Pakar, 2-17.

Arakal, T., \& Mampilly, D. S. R. (2013). The Impact of Organizational Climate on Performance of Employees, 4. 
Astuti, N. L. P., Mimba, N., \& Ratnadi, N. M. D. (2016). Pengaruh Work Engagement pada Kinerja Bendahara Pengeluaran dengan Kepemimpinan Transformasional Sebagai Pemoderasi. E-Jurnal Ekonomi dan Bisnis Universitas Udayana, 5(2016), 4057-4082.

Bakker, A. B. (2011). An Evidence-Based Model of Work Engagement. Current Directions in Psychological Science, 20(4), 265-269.

Bakker, A. B., \& Demerouti, E. (2008). Towards a Model of Work Engagement. Career Development International.

Dewi, N. K., Hermawan, A., \& Affandi, M. J. (2019). Pengaruh Job Characteristics dan Leader Member Exchange (LMX) Terhadap Work Engagement di PT Elang Perdana Tyre Industry. Jurnal Aplikasi Bisnis dan Manajemen (JABM), 5(3), 430.

Findıklı, M. A., Yozgat, U., \& Rofcanin, Y. (2015). Examining Organizational Innovation and Knowledge Management Capacity the Central Role of Strategic Human Resources Practices (SHRPs). Procedia-Social and Behavioral Sciences, 181, $377-$ 387.

Harris, T. B., Li, N., \& Kirkman, B. L. (2014). Leader-member Exchange (LMX) in Context: How LMX Differentiation and LMX Relational Separation Attenuate LMX's Influence on OCB and Turnover Intention. The Leadership Quarterly, 25(2), 314-328.

Hutama, P., \& Goenawan, R. (2017). Pengaruh Leader Member Exchange terhadap Kinerja Karyawan di Hotel X Surabaya. Jurnal Hospitality Dan Manajemen Jasa, $5(2)$.

Justina, S., Susetyo, S., \& Kananlua, P. (2019). Pengaruh Leader-Member Exchange Terhadap Kinerja Karyawan Melalui Peran Variabel Mediasi Work Engagement Pada Pt. Perusahaan Listrik Negara (Persero) Area Bengkulu. Managament Insight: Jurnal Ilmiah Manajemen, 14(1), 51-62.

Liden, R. C., \& Maslyn, J. M. (1998). Multidimensionality of Leader-Member Exchange: an Empirical Assessment Through Scale Development. Journal of Management, 24(1), 43-72.

Liliweri, A. (2014). Sosiologi dan komunikasi organisasi. Jakarta: Bumi Aksara.

Luthans, F., Youssef, C. M., \& Rawski, S. L. (2011). A Tale of Two Paradigms: The Impact of Psychological Capital and Reinforcing Feedback on Problem Solving and Innovation. Journal of Organizational Behavior Management, 31(4), 333-350.

Maslyn, J. M., \& Uhl-Bien, M. (2001). Leader-Member Exchange and its Dimensions: Effects of Self-Effort and Other's Effort on Relationship Quality. Journal of Applied Psychology, 86(4), 697.

Meng, F., \& Wu, J. (2015). Merit Pay Fairness, Leader-Member Exchange, and Job Engagement: Evidence from Mainland China. Review of Public Personnel Administration, 35(1), 47-69.

Putra, P., Liriwati, F. Y., Tahrim, T., Syafrudin, S., \& Aslan, A. (2020). The Students Learning From Home Experience During Covid-19 School Closures Policy in Indonesia. Jurnal Iqra, 5(2). 
Rahmadalena, T., \& Asmanita, A. (2020). Pengaruh Employee Engagement, Karakteristik Pekerjaan Terhadap Kinerja Karyawan pada PT. Bukit Asam, TBK Unit Dermaga Kertapati Palembang. Jurnal Ilmiah Bina Manajemen, 3(2), 68-76.

Salu, O. J., \& Hartijasi, Y. (2018). Analisis Pengaruh Work Engagement Sebagai Mediator Antara Job Resources dan Kepemimpinan Transformasional Terhadap Organizational Commitment and Job Performance di Lembaga Pendidikan Indonesia Amerika. Jurnal Bisnis, Manajemen, Dan Informatika, 14(3).

SARI, D. W. (2016). Hubungan Antara Persepsi Pada Leader-Member Exchange (Lmx) dengan Work Engagement pada Karyawan Tetap Non-Manajerial di Rumah Sakit Bedah Surabaya. Universitas Airlangga.

Schaufeli, W. B., Salanova, M., González-Romá, V., \& Bakker, A. B. (2002). The Measurement of Engagement and Burnout: A Two Sample Confirmatory Factor Analytic Approach. Journal of Happiness Studies, 3(1), 71-92.

Selamat, N., Samsu, N. Z., \& Kamalu, N. S. M. (2013). The Impact of Organizational Climate on Teachers' Job Performance.

Sepdiningtyas, R. (2016). Pengaruh Leader-Member Exchange Terhadap Kinerja Individual dengan Pemediasi Work Engagement dan Pemoderasi Dukungan Rekan Kerja. Universitas Gadjah Mada.

Shafarila, A. W., \& Supardi, E. (2016). Iklim Organisasi dan Motivasi Kerja Sebagai Diterminan Kinerja Pegawai. Jurnal Pendidikan Manajemen Perkantoran (JPManper), 1(1), 19-29.

Suandi, T., Ismail, I. A., \& Othman, Z. (2014). Relationship Between Organizational Climate, Job Stress and Job Performance Officer at State Education Department. International Journal of Education and Literacy Studies, 2(1), 17-28.

Sugiyono. (2014). Metode Penelitian Pendidikan Pendekatan Kuantitatif, Kualitatif, dan R\&D. Bandung: Alfabeta.

Suliman, A., \& al Harethi, B. (2013). Perceived Work Climate and Employee Performance in Public Security Organizations in the UAE. Transforming Government: People, Process and Policy.

Tweddell, J. S., Hoffman, G. M., Mussatto, K. A., Fedderly, R. T., Berger, S., Jaquiss, R. D. B., Ghanayem, N. S., Frisbee, S. J., \& Litwin, S. B. (2002). Improved Survival of Patients Undergoing Palliation of Hypoplastic Left Heart Syndrome: Lessons Learned from 115 Consecutive Patients. Circulation, 106(12_suppl_1), I-82.

Wulandari, S. M., \& Ratnaningsih, I. Z. (2017). Hubungan antara Leader Member Exchange (LMX) dengan Work Engagement pada Perawat Instalasi Rawat Inap di RSJD Dr. Amino Gondohutomo Semarang. Jurnal Empati, 5(4), 721-726.

Yukl, G. A., \& Becker, W. S. (2006). Effective Empowerment in Organizations. Organization Management Journal, 3(3), 210-231. 